\title{
The Implementation of Community-based Ecotourism Concept in Osing Tourism Village Development Strategy of Banyuwangi Regency, Indonesia
}

\author{
Wiwin Indiarti, S.S., M.Hum \\ Faculty of Language and Art \\ PGRI University of Banyuwangi \\ Banyuwangi, Indonesia \\ wiwinindiarti@gmail.com
}

\author{
Abdul Munir, M.Pd. \\ Faculty of Language and Art \\ PGRI University of Banyuwangi \\ Banyuwangi, Indonesia \\ monaire32@yahoo.com
}

\begin{abstract}
Rural tourism is one of the sectors having potency and opportunity to develop as the optimization of rural resources in the fighting against poverty. One of the approaches which can be used to develop rural tourism activities is Community-based Ecotourism (CBE) concept in the form of tourism village. Different from conventional tourism, CBE gives direct impact to the area conservation, takes role in the local community economic empowerment efforts and enhances both sustainable conservation and development.
\end{abstract}

This research-based article aims at 1 . identifying and assessing rural potencies and tourist attractions in Osing culturebased village in Tourism Development Zone 1 (TDZ 1) of Banyuwangi regency; 2. analyzing the readiness of both $\mathrm{CBE}$ implementation and the community; and 3. designing guidelines of tourism village development strategy with CBE concept.

The research takes place in Kemiren Village of Glagah District Banyuwangi because Kemiren is considered as the most representative of Osing culture-based indigeneous villages. The tourist attraction assessment is based on 5 aspects: attractions, accessibility, condition of socio-economic environments, accommodation and supporting facilities. The readiness assessment of $\mathrm{CBE}$ development is based on 4 scoring aspects: socio-economic, environmental, and management aspects. The community readiness assessment in the tourism village development with $\mathrm{CBE}$ concept is based on the community characteristics, perception, participation and wishes. Each of the assessment result will be analyzed and ranked in 5 scoring classes: very good, good, medium, bad and very bad.)

Keywords - tourism village; CBE; development strategy

\section{INTRODUCTION}

Tourism in these five years has been recognized as one of the potential winnings and basis for the economic growth in Banyuwangi Regency, East Java, Indonesia. The government optimizes the management of abundant natural resources and diverse culture in this field by launching The Triangle Diamond as the brand for its Tourism Development Zones (TDZ): Ijen Zone (TDZ I), Plengkung Zone (TDZ II) and Sukamade Zone (TDZ III). The zonation system proved to be effective in the tourism management of a very vast region as Banyuwangi.

Recently, the regional government promotes sustainable rural tourism development. Other than having big potency of natural tourism objects (beaches, parks, forest and geology), Banyuwangi is also supported by tailor-made tourist attractions still related to natural and cultural tourism characterized by traditional lifestyles and historical heritage. The passion for conducting tourism village development grows from a belief that tourist attraction potencies owned by the regency such as nature, culture and traditions can entice both the domestic or international tourists to come. The opportunity occurs by the focus shifting of psycho-graphical and demographical aspects of tourists (either individual or group) all over the world stepping aside from a massive conventional tourism to the kind of alternative tourism form giving more responsibility to the environment (Mowforth \& Munt, 1998; Cooper \& Hall, 2008; Fandeli, 2002; Damanik \& Weber, 2006).

The number of tourism villages in Indonesia has sharply increased from year to year. According to Ministry of Tourism data, Indonesia in 2012 has already had 978 tourism villages and in 2014 the number becomes not more than 1400. The development of tourism village and its technicalities needs strategy and supports from the whole community members and stakeholders. Some experts relate the term tourism village to tourism activities growth in rural areas (Parekh, 2010; Page \& Getz, 1997:4). Tourism village can be defined as a village designed consciously- or naturally having capability- to attract visitors to come because of the natural and cultural attraction potencies. The concept used by the planners of rural tourism development in Indonesia is the one defined as "integrated form of attractions, accommodation and supporting facilities presented in a structure of community life comingled with the local traditions" (Tourism Minister of Indonesian Republic, 2011). The operational definition functions as a basis for the policies on rural tourism development in Indonesia. Therefore, the term tourism village can be defined as similar to rural tourism.

Compared to the concept of tourism village, rural tourism is often found in diverse academic publications (Youell, 1996; Page and Getz, 1997; Kuvacic, et al., 2010; Chuang, 2010). However, there are no significant differences between them. 
Having summarized some experts' theories, Chuang (2010:1313) and Kuvacic, et al., (2010: 1648) then formulate the definition of rural tourism by referring to a geographical sphere having indigenous characteristics comprising traditional culture, agriculture, inlands and also simple lifestyles where tourism activities take place. The context of space, then, becomes important in positioning activities and impacts of rural tourism development. Another expert defines rural tourism as "one of the forms of sustainable development that, through promoting productivity in rural zones, 1) brings about employment, income distribution, preservation of village environment and local culture, 2) raising local community participation and 3) presenting appreciate methods to conform beliefs and traditional values with new circumstances" (Youell, 1996: 136). Rural tourism as an alternative tourism proved to be able in contributing positive impacts to social, economic, and cultural resources of rural zones.

Rural tourism considered as a sector with potency and opportunity to develop as a form of optimizing rural resources in fighting against poverty. Recent development in tourism field has increased the tendency to manage local potencies, especially of villages, by using community-based strategy. As an alternative tourism, tourism village development is based on the local potencies and unique characteristics: flora, fauna, traditional house, natural views, climate, traditional food, handicrafts, traditional arts and customs, etc. The management of rural tourism resources should be supported by the community and stakeholders. Started from this point, then their position becoming very important not only as an effort in making them magnets for tourist coming, but also more as the preservation of ecological and cultural resources.

The growth of tourism development not only gives social, economic, and cultural implications for society, but also provides negative impacts if it is not well-prepared and managed. One of the approaches to develop rural tourism is the Community-based Ecotourism (CBE) concept in the form of tourism village. Different from conventional tourism, $\mathrm{CBE}$ is a concept of tourism development giving direct impacts to the area conservation, takes role in the local community economic empowerment, and enhances sustainable development.

The article is based on a research conducted at Kemiren Village in the TDZ I. Kemiren is blessed with tourism potencies which are based on the traditions, customs, culture and arts of Osing people regarded as the indigenous people of Banyuwangi. Kemiren tourism village has made continual progress since the launching of tourism village concept as an alternative tourism in Indonesia. Development of Kemiren tourism village could give positive impact not only for the environment and economy, but also for empowering the local people of Kemiren. Based on these conditions, therefore, the aim of this study is to analyze the implementation of $\mathrm{CBE}$ concept in Osing tourism village development strategy.

\section{METHOD}

The article is based on a research aiming at (1). identifying and assessing the tourist attractions and objects in Osing culture-based tourism village in Banyuwangi Regency; (2). analyzing the readiness level of $\mathrm{CBE}$ implementation in
Osing culture-based tourism village in Banyuwangi Regency; and (3). setting the direction of the development strategy of tourism village by using CBE concept in Osing culture-based tourism village in Banyuwangi Regency. The research location is Kemiren Village in Glagah District - Banyuwangi, which is the most representative of Osing culture-based villages in Banyuwangi.

The Primary and secondary data are collected by library study, observation, interview and questionnaire. The assessment method of tourist attractions and objects is based on the assessment criteria having been determined in the Scoring Guidance of Tourist Attractions (Department of Tourism and Culture 2001). The assessment of tourism objects and attractions is based on 5 aspects: attractiveness, accessibility, economic and social condition, accommodation and other supporting facilities. The assessment method of the readiness on $\mathrm{CBE}$ development follows the standardized design of $\mathrm{CBE}$ made by WTO (2004) and INDECON (2008). The assessment on the readiness of CBE development is based on 4 aspects: socio-economic, socio-cultural, environment and management aspects. The assessment method of the community readiness is done through questionnaires distributions. The assessment on the readiness of tourism village development by using $\mathrm{CBE}$ concept is based on the characteristics, perception, participation and wishes of the community. The respondents are 30 Kemiren people determined by random sampling technique.

Data analysis technique is used to evaluate the 3 components of assessment (tourism objects and attractions, readiness in the $\mathrm{CBE}$ development and community readiness in the ecotourism development). Data related to the three assessment components will be counted to determine the score of each component by using the following equation (Untari, 2006):

Notes:

$$
\mathrm{S}=\mathrm{N} \times \mathrm{B}
$$

$\mathrm{S}=$ Score; $\mathrm{N}=$ Total score of items on the criteria; $\mathrm{B}=$ Weight

Assessment is classified based on the total number of each assessment component. The range of assessment classification will be counted by using the following equation (Untari, 2006):

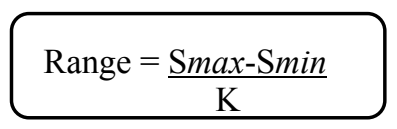

Notes:

Range $=$ Range of score in the determination of assessment classification range; Smax $=$ Highest score; Smin=Lowest score; $\mathrm{K}=$ The number of assessment classification

Each of the assessment result will be analyzed and classified into 5 ranks: very good, good, medium, bad and very bad. As perfection, SWOT analysis is done to formulate tourism village development strategy by using CBE concept.

\section{FINDINGS AND DISCUSSION}

Kemiren is both a tourism village and Osing cultural heritage lies in the main road to the famous Ijen Crater. Kemiren inhabited by 2.577 people in an area comprising 
$117.052 \mathrm{~m} 2$ (Profile of Kemiren Village, 2015). Five meter wide asphalt road divides this village which is the only way to get to the city center in the eastern side. The main potency of this tourism village is the rural natural landscape comingled in harmony with the preserved tradition and culture of Osing people.

Most of Kemiren area consists of paddy fields and plantations. Two big rivers which become the village boundaries on the North and South sides along with the existence of 25 springs make the paddy fields and plantations fertile with diverse crops. The rustic aroma intensified in the wrapped of arts, traditions and culture of agricultural society which existences have been maintained until nowadays.

Rustic feel is still fresh in Kemiren. The views of women with baskets on their heads and buckets in their hands swinging steps towards paddy fields oftenly seen in growing season to harvest time. Paddy fields for Kemiren people mean their lifeblood. No wonder then if the whole arts, traditions and culture of Kemiren people deeply rooted from the fields- as a form of gratitude to God, nature and the ancestors. Agrarian rites in the form of paddy cultivation tradition are still done. The atmosphere of paddy fields and traditional farming becoming thicker because the surroundings are decorated with the existence of traditional architectural constructions in the forms of paglak (bamboo small huts higher than $6 \mathrm{~m}$ ) and kiling (a very tall bamboo structure with a big propeller on top).

The artistic expressions can also deeply felt because of various traditional arts of Osing people like Gandrung, Barong, Kuntulan, Angklung, Burdah, Jaran Kencak, Mocoan Lontar Yusuf and Gedhogan. All the diverse arts performed periodically or impromptu in Kemiren and then become attractions that entice both domestic and foreign tourists to come. There are also other tourism attractions in the forms of communal rites which annually conducted with fanfare. They are Barong Ider Bumi and Tumpeng Sewu. These communal rites of village cleansing ceremony have been fixed agenda and included in the calendar of tourism events published by the local government. Tumpeng Sewu rite has been stated in 2015 as the national non-material cultural heritage by the Department of Education and Culture. When the two rituals are conducted, thousands of visitors flood the main roads of Kemiren Village.

To fulfill the need of the visitors coming to the village, the local people have provided dozens of homestays as alternative to spend the nights. As for those who do not want to stay in homestays, there are also accommodations provided in the Anjungan Desa Wisata Osing; a travel bridge built to be the Kemiren miniatur or the museum-like of Osing culture. Since 2015 , the village government and society members starting to make preparations in improving facilities supporting tourism, like the building of information center for village tourism and souvenirs or crafts vendors.
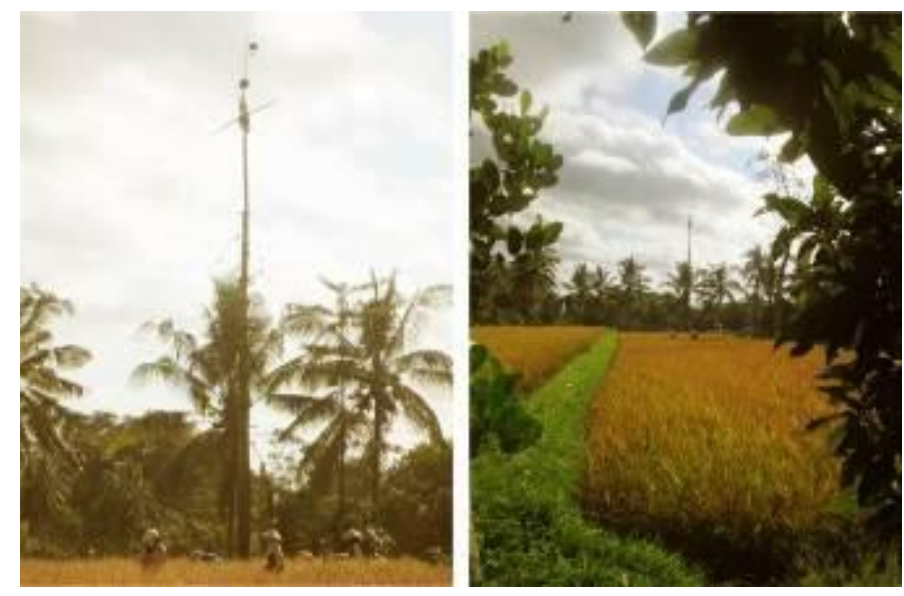

Fig. 1. Landscape of paddy fields and farmers' daily routine in Kemiren.

\section{A. The Assessment of Tourist Attractions and Objects in Kemiren}

The identification and assessment of tourism resources of Kemiren comprise 5 aspects: tourist attractions (TA), accessibility (A), condition of economic and social environments (CESE), accommodation (ACC) and supporting facilities (SP), as seen in table I. Based on the evaluation of tourist attractions aspect, Kemiren is ranked as good. This is a pretty good stock to be managed optimally to increase the local people welfare through the implementation of tourism village program.

TABLE I. THE ASSESSMENT OF TOURIST ATTRACTIONS AND OBJECTS IN KEMIREN

\begin{tabular}{|c|c|c|c|c|c|c|}
\hline Criteria & TA & $\mathbf{A}$ & CESE & $\mathbf{A C C}$ & SP & \multirow{3}{*}{$\begin{array}{l}\text { Total } \\
\text { score }\end{array}$} \\
\hline Weight & 6 & 5 & 5 & 3 & 3 & \\
\hline Basic Score & 160 & 120 & 75 & 40 & 60 & \\
\hline Score & 960 & 600 & 375 & 120 & 180 & 2235 \\
\hline
\end{tabular}

Notes: 2.640-2.328 (very good); 2.327-2.016 (good); 2.015-1.704 (medium); 1.703-1.392 (bad); 1.391-1.080 (very bad)

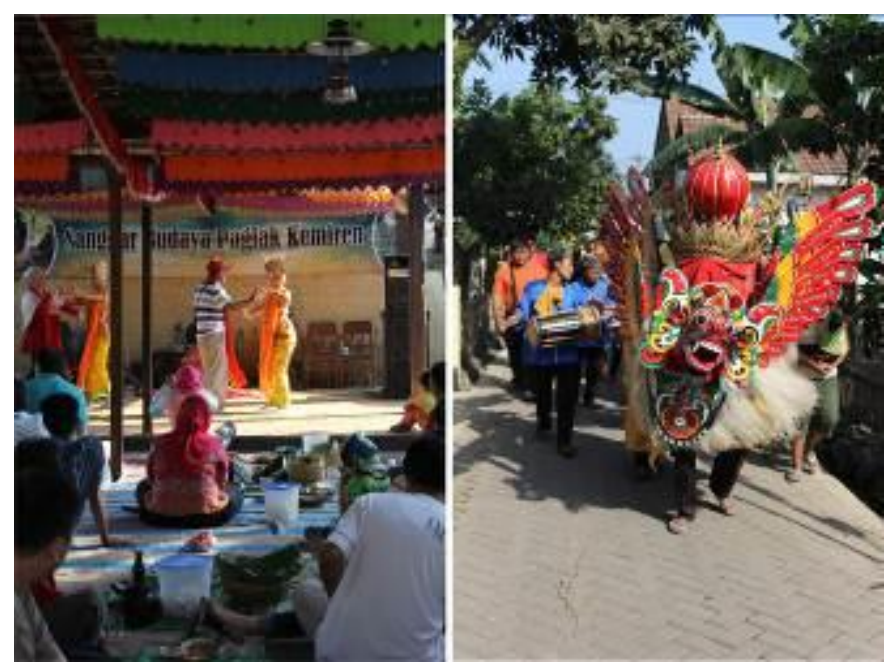

Fig. 2. Gandrung dance and Barong performance art - two Osing traditional arts - which become parts of tourism attractions in Kemiren. 


\section{B. The Readiness Assessment of CBE Implementation in Kemiren}

CBE is an ecotourism concept of development which both involves and posits the local community as the total controller in its management and development so that it contributes to society like increasing the local community welfare and promoting local culture sustainability. The evaluation on the readiness of this $\mathrm{CBE}$ implementation is divided into 4 aspects of evaluation. They are socio-economic aspect (SOCEC), socio-cultural aspect (SOCUL), environment aspect (ENV) and management aspect (MAN) as seen in tabel II.

TABLE II. The READINESS ASSESSMENT OF CBE IMPLEMENTATION IN KEMIREN

\begin{tabular}{|l|r|r|r|r|l|}
\hline Criteria & \multicolumn{1}{|l|}{ SOCEC } & \multicolumn{1}{l|}{ SOCUL } & \multicolumn{1}{l|}{ ENV } & \multicolumn{1}{l|}{ MAN } & Total \\
\cline { 1 - 5 } Weight & 6 & 6 & 6 & 6 & Score \\
\cline { 1 - 5 } Basic Score & 120 & 60 & 55 & 90 & \\
\hline Score & 720 & 360 & 330 & 540 & 1950 \\
\hline
\end{tabular}

Notes: 2.040-1.836 (very good); 1.835-1.632 (good); 1.631-1.428 (medium); 1.427-1.224 (bad); $1.223-1.020$ (very bad)

Based on the readiness assessment of CBE development, Kemiren has score 1950 which is classified as very good. The development of socio-cultural aspect, especially related to the criteria of preservation, appreciation and management have to be continually increased in order to be better.

\section{The Community Readiness Assessment of $C B E$ Implementation in Kemiren}

In the assessment of CBE implementation, community considered as one of the important stakeholders. The assessment questionnaire is divided into 3. They are community characteristics (CC), perception on ecotourism development (PED), and participation level and community wishes (LPCW). Based on the questionnaire, it can be taken the result of total assessment of community readiness as seen in table III.

TABLE III. THE COMMUNITY READINESS ASSESSMENT IN ECOTOURISM DEVELOPMENT

\begin{tabular}{|c|c|c|c|c|}
\hline Criteria & $\mathbf{C C}$ & PED & LPCW & Total \\
\hline Weight & 5 & 6 & 6 & Score \\
\hline Basic Score & 100 & 120 & 120 & \\
\hline Score & 500 & 720 & 720 & 1940 \\
\hline
\end{tabular}

Notes: 2.040-1.910 (very good); 1.909-1.710 (good); 1.709-1.510 (medium); 1.509-1.310 (bad); $1.309-1.110$ (very bad)

Based on the community readiness assessment aspect in the ecotourism development, Kemiren given score 1940 and classified as very good. It shows that the participation level of Kemiren people in the management of rural tourism is very high. The community's characteristics which mostly the indigeneous people can be considered as plus point to involve society in the management of rural tourism.

\section{Internal Factor Analysis Summary (IFAS) and External Factor Analysis Summary (EFAS) of Ecotourism Development in Kemiren}

In order to determine the strategy for developing ecotourism in Kemiren, the reseachers do SWOT (strength, weakness, opportunity and threat) analysis based on the result of the assessment on the tourist attractions and objects, the readiness on the $\mathrm{CBE}$ implementation and the community readiness in ecotourism development completed with the real condition or ground-true-check. Strengths and weaknesses are called as internal factor while factors coming from the outside of the village (opportunities and threaths) are called as the external factors.

IFAS and EFAS in the development of ecotourism in Kemiren can be seen in table IV and V.

TABLE IV. FACTORS OF INTERNAL STRATEGy BASED ON THE SWOT ANALYSIS

\begin{tabular}{|c|c|c|c|c|}
\hline IFAS & Weight & Rating & Score & Code \\
\hline \multicolumn{5}{|l|}{ STRENGTHS (S) } \\
\hline Rural natural landscape & 0,15 & 4 & 0,6 & S1 \\
\hline $\begin{array}{l}\text { Kemiren people are the Osingnese } \\
\text { (considered as the indigenous people of } \\
\text { Banyuwangi) }\end{array}$ & 0,15 & 4 & 0,6 & S2 \\
\hline $\begin{array}{l}\text { Kemiren strategic location which is near } \\
\text { the city center }\end{array}$ & 0,1 & 3 & 0,3 & S3 \\
\hline Kemiren people open heartedness & 0,05 & 4 & 0,1 & S4 \\
\hline $\begin{array}{l}\text { The abundant of Osing traditions, arts } \\
\text { and culture }\end{array}$ & 0,1 & 4 & 0,4 & S5 \\
\hline High level of community participation & 0,05 & 3 & 0,15 & S6 \\
\hline \multicolumn{5}{|l|}{ WEAKNESSES $(\mathrm{W})$} \\
\hline Weak coordination & 0,1 & 1 & 0,1 & W1 \\
\hline Weak competitiveness & 0,1 & 1 & 0,1 & W3 \\
\hline Low level of human resources & 0,1 & 2 & 0,2 & W4 \\
\hline $\begin{array}{l}\text { Inadequate information about the tourist } \\
\text { attractions }\end{array}$ & 0,05 & 2 & 0,1 & W5 \\
\hline $\begin{array}{l}\text { The inexistence of tourism products } \\
\text { related to rural natural resources }\end{array}$ & 0,05 & 2 & 0,1 & W6 \\
\hline Total & 1 & & 2,67 & \\
\hline
\end{tabular}

TABLE V. FACTORS OF EXTERNAL STRATEGy BASED ON THE SWOT ANALYSIS

\begin{tabular}{|l|l|l|l|l|}
\hline \multicolumn{1}{|c|}{ IFAS } & Weight & Rating & Score & Code \\
\hline OPPORTUNITIES (O) & 0,15 & 3 & 0,45 & O1 \\
\hline Supports from the government & 0,15 & 3 & 0,45 & O2 \\
\hline $\begin{array}{l}\text { The advancement of information and } \\
\text { technology }\end{array}$ & 0,15 & 2 & 0,3 & O3 \\
\hline $\begin{array}{l}\text { Kemiren is near other villages having } \\
\text { tourism potencies as well }\end{array}$ & 0,15 & 3 & 0,45 & O5 \\
\hline $\begin{array}{l}\text { The existence of higher institution with } \\
\text { its research center as society and } \\
\text { government partners }\end{array}$ & & & & \\
\hline THREATHS (T) & 0,2 & 1 & 0,2 & T1 \\
\hline $\begin{array}{l}\text { Jealousy among villages related to } \\
\text { tourism development }\end{array}$ & 0,2 & 1 & 0,2 & T2 \\
\hline Inadequate public transportation & $\mathbf{1}$ & & $\mathbf{2 , 6 5}$ & \\
\hline Total & & & & \\
\hline
\end{tabular}




\section{E. Tourism Village Development Strategy with CBE Concept in Kemiren Village}

TABLE VI. The Priority OF DEVELOPMENT STRATEGY OF KEMIREN BY USING CBE CONCEPT BASED ON SWOT ANALYSIS

\begin{tabular}{|c|c|c|c|}
\hline Development Strategy & $\begin{array}{c}\text { Code of } \\
\text { Weighting }\end{array}$ & Total & Priority \\
\hline \multicolumn{4}{|l|}{ SO } \\
\hline Increasing the community participation & $\begin{array}{l}\mathrm{S} 2+\mathrm{S} 6+\mathrm{S} 5+\mathrm{O} 1 \\
+\mathrm{O} 5\end{array}$ & 2,05 & 1 \\
\hline $\begin{array}{l}\text { Increasing the community understanding } \\
\text { on the importance of nature conservation } \\
\text { and Osing cultural values }\end{array}$ & $\mathrm{S} 1+\mathrm{S} 5+\mathrm{S} 6+\mathrm{O} 5$ & 1,6 & 2 \\
\hline $\begin{array}{l}\text { Having coordination and cooperation in } \\
\text { promotion with tourism objects manager of } \\
\text { the closest areas. }\end{array}$ & $\mathrm{S} 3+\mathrm{O} 2+\mathrm{O} 3$ & 1,05 & 6 \\
\hline $\begin{array}{l}\text { Having coordination and cooperation with } \\
\text { higher institution, especially the research } \\
\text { centers as partner in tourism development. }\end{array}$ & $\mathrm{S} 4+\mathrm{O} 5$ & 0,55 & 9 \\
\hline \multicolumn{4}{|l|}{ ST } \\
\hline $\begin{array}{l}\text { The development of local potency-based } \\
\text { tourism village in other villages in Glagah } \\
\text { District. }\end{array}$ & $\mathrm{S} 3+\mathrm{T} 1+\mathrm{T} 2$ & 0,7 & 8 \\
\hline $\begin{array}{l}\text { Increasing cooperation with other villages } \\
\text { having tourism potencies in tourism } \\
\text { development. }\end{array}$ & $\mathrm{S} 3+\mathrm{T} 1$ & 0,5 & 11 \\
\hline \multicolumn{4}{|l|}{ WO } \\
\hline $\begin{array}{l}\text { Increasing synergy and coordination } \\
\text { among stakeholders in Kemiren tourism } \\
\text { development. }\end{array}$ & $\mathrm{W} 1+\mathrm{O} 1+\mathrm{S} 6$ & 1,45 & 3 \\
\hline $\begin{array}{l}\text { Enhancing the growth of creative } \\
\text { industries and marketing facilities based on } \\
\text { the local knowledge as the supporters of } \\
\text { tourism development. }\end{array}$ & $\begin{array}{l}\mathrm{W} 3+\mathrm{W} 4+\mathrm{O} 1+ \\
\mathrm{W} 6+\mathrm{O} 5\end{array}$ & 1,3 & 4 \\
\hline $\begin{array}{l}\text { Enhancing promotion and integrated } \\
\text { information service about tourism program }\end{array}$ & $\mathrm{W} 5+\mathrm{O} 2+\mathrm{O} 5$ & 1 & 7 \\
\hline $\begin{array}{l}\text { Increasing human resources quality in the } \\
\text { management of tourism village }\end{array}$ & $\begin{array}{l}\mathrm{W} 4+\mathrm{W} 1+\mathrm{O} 1+ \\
\mathrm{O} 5\end{array}$ & 1,2 & 5 \\
\hline $\begin{array}{l}\text { Creating community-based tourism } \\
\text { program }\end{array}$ & $\mathrm{W} 6+\mathrm{O} 1$ & 0,55 & 10 \\
\hline \multicolumn{4}{|l|}{ WT } \\
\hline $\begin{array}{l}\text { Procurement of transportation access and } \\
\text { other facilities by using sustainable tourism } \\
\text { concept. }\end{array}$ & $\mathrm{W} 5+\mathrm{T} 2$ & 0,3 & 12 \\
\hline
\end{tabular}

The next step is to know which strategy becoming the priority. Therefore, the researcher has to arrange alternative strategy in SWOT analysis. All of the code of weighting being summarized counted in one of development strategy. The final result of SWOT analysis shows which priority to make in CBE development in Kemiren as seen in table VI.

Based on the alternative strategy of the SWOT analysis in the tourism village development with $\mathrm{CBE}$ concept, 4 strategies are resulted: SO, ST, WO dan WT. Those 4 strategies can be translated into 12 (twelve) recommended priorities. Those twelve priorities are divided into two strategies of priority: internal and external reinforming strategies. The internal reinforming of strategic priority related to capacity and human resources of Kemiren people in the development of tourism village. Meanwhile, the external reinforming of strategic priority related to promoting cooperation with other parties in tourism village development. The internal reinforming of strategic priority contained in strategic priority number $1,2,4,5$ and 10 , while the external one contained in strategic priority number $3,6,7,8,9,11$, and 12.

\section{CONCLUSION AND SUGGESTION}

Based on the potencies of objects and tourist attractions and community readiness, it is potential to develop Kemiren as tourism village with $\mathrm{CBE}$ concept. The components of attraction having high score are in the forms of rural landscape, culture and traditions of Osing people which are continually preserved.

The analysis of CBE implementation level in Kemiren nowadays shows high level of community participation. However, the planning and evaluating in the tourism village development should be improved in the development of tourism village giving priority to sinergy and coordination between stakeholders in the development of Kemiren. Besides, the efforts in maintaining Osing arts, traditions and culture should be continually done together with the efforts in giving understanding to the people on the importance of nature and culture conservation as the basis for $\mathrm{CBE}$ development in Kemiren.

Result of the assessment of internal and external factors in the development of Osing tourism village with CBE concept as a whole can be formulated in 12 prioritized development strategies comprising: (1) increasing the community participation; (2) increasing the community understanding on the importance of nature conservation and Osing cultural values; (3) increasing synergy and coordination among stakeholders in Kemiren tourism developmen; (4) enhancing the growth of creative industries and marketing facilities based on the local knowledge as the supporters of tourism development; (5) increasing human resources quality in the management of tourism village; (6) having coordination and cooperation in promotion with tourism objects manager of the closest areas.; (7) enhancing promotion and integrated information service about tourism program; (8) developing the local potency-based tourism village in other villages in Glagah District; (9) having coordination and cooperation with higher institution, especially the research centers as partner in tourism development.; (10) creating community-based tourism program ; (11) increasing cooperation with other villages having tourism potencies in tourism development.; and (12) procurement of transportation access and other facilities by using sustainable tourism concept.

It is, then, suggested that in the development of Kemiren tourism village with $\mathrm{CBE}$ concept the growth of synergies between villagers, government and stakeholders should be forged in order to increase people awareness towards area conservation, ecology and culture along with the implementation of tourism village development.

\section{ACKNOWLEDGMENT}

The authors deliver their gratitudes to DP2M KEMENRISTEK DIKTI (Direktorat Penelitian dan Pengabdian Masyarakat - Minister of Research and Higher Education) for funding this 2016 Research of Hibah Bersaing. 


\section{REFERENCES}

[1] Chuang, S., "Rural tourism: Perspectives from social exchange theory," Social Behavior and Personality: An International Journal, vol. 38, pp. 1313-1322, 2010.

[2] Cooper, C. \& Hall, C. M., "Contemporary tourism: an international approach,” Oxford: Elseiver, 2008.

[3] Damanik, J. \& Weber, H., "Perencanaan ekowisata: dari teori ke aplikasi," Yogyakarta: Andi, 2006.

[4] Fandeli, C., "Perencanaan kepariwisataan alam," Yogyakarta: Faculty of Forestry-Gadjah Mada University, 2002.

[5] INDECON, "Rancangan standardisasi pengembangan community based ecotourism," A paper presented in Tourism Convension ECEATINDECON in Nusa Dua Bali, 13-16 March 2008.
[6] Minister of Tourism of Indonesian Republic, "Rule number: km.18/ hm.001/ mkp/ 2011 on the Guide of National Program of Community Empowerment (PNPM Mandiri) of Tourism," Jakarta: Ministry of Tourism of Indonesian Republic, 2011.

[7] Mowforth, M. \& Munt, I., "Tourism and sustainability, new tourism in the third world," London \& New York: Routledge, 1998.

[8] Page, S. \& Getz, D. (Eds.), "The business of rural tourism: international perspectives," London: International Thomson Business Press, 1997.

[9] Parekh, M.A., "Fair-based rural tourism: a potential growth engine for rural economy in Gujarat," The IUP Journal of Infrastructure, vol. 8, pp. 83-92, 2010.

[10] Youell, R., "The complete a-z leisure, travel and tourism handbook," London: Hodder \& Stoughton, 1996.

[11] Untari, Rini, "Strategi pengembangan ekowisata berbasis masyarakat di zona wisata Bogor Barat Kabupaten Bogor,” Thesis of Graduate Studies of Bogor Institute of Agriculture, 2009. 